\title{
ASSESSMENT OF FOOD CROP FARMERS INDIGENOUS STRATEGIES TO CLIMATE CHANGE MITIGATION AND ADAPTATION IN IMO STATE, NIGERIA
}

\author{
Chidiebere-Mark, N.M. ${ }^{1 *}$, Ejike, R.D. ${ }^{1}$, Nwaiwu, J.C. ${ }^{1}$, Nwankwo, O.O. ${ }^{1}$ \& Ibe, G.O. ${ }^{2}$ \\ 1. Department of Agricultural Economics, Extension and Rural Development, Imo State University, \\ Owerri, Imo State, Nigeria. \\ 2. Department of Agricultural Technology, Federal Polytechnic, Owerri, Nigeria.
}

*nnekamark@gmail.com

\begin{abstract}
Food crop farmers' indigenous strategies to climate change mitigation and adaptation in Imo State, Nigeria was analyzed. The specific objectives were to; ascertain food crop farmers' awareness of climate change; determine the farmers' perceived effects of climate change on food crop production in the study area; identify the indigenous strategies adopted in climate change mitigation and adaptation as well as identify constraints faced by farmers in mitigating and adapting to climate change in the study area. The study used 2018 survey data from rural farming households which were selected using a random sampling technique. The farmers (65.30\%) were aware of climate change effects on crop production. Indigenous strategies used include use of disease resistant varieties (58.33\%), livelihood diversification (37.50\%) and agro forestry practices (63.89\%).The study recommends the establishment of research institutes to investigate successful adaptation and mitigation measures for scaling up and down as well as expansion of agricultural extension advisory services to educate farmers on indigenous strategies to mitigate climate change effect on crop production.
\end{abstract}

Keywords: Perceived, Awareness, Indigenous, Climate Change, Farmers

https://dx.doi.org/10.4314/jafs.v16i2.9

\section{INTRODUCTION}

Agricultural practices are major anthropogenic contributors to climate change (IPCC, 2010). According to IPCC (2007), agriculture accounts for about 14 percent of greenhouse gas emissions or approximately 30 percent of global emissions. Agricultural activities that contribute to GHG emissions include; emissions of nitrous oxide $\left(\mathrm{N}_{2} \mathrm{O}\right)$ from the application of synthetic and organic fertilizers, the growth of nitrogen-fixing crops, the drainage of organic soil and irrigation practices; livestock such as cattle produce methane $\left(\mathrm{CH}_{4}\right)$; manure treatment and storage methods affect how much of these greenhouse gases $\left(\mathrm{CH}_{4}\right.$ and $\mathrm{N}_{2} \mathrm{O}$ emissions) are produced. Smaller sources of agricultural emissions include $\mathrm{CO}_{2}$ from liming and urea application, $\mathrm{CH}_{4}$ from rice cultivation, and burning crop residues, which produces $\mathrm{CH}_{4}$ and $\mathrm{N}_{2} \mathrm{O}$ (www.epa.gov/ghgemissions accessed $\underline{12 / 07 / 2019)}$.

The consequences of climate change are global and it affects every sector of the economy, especially the poor and vulnerable group. Given the speed at which climate change is occurring

Journal of the Faculty of Agriculture and Veterinary Medicine, Imo State University Owerri website: www ajol.info 
globally, it is urgent that the vulnerability of developing countries to climate change impacts is reduced while their capacity to adapt is increased and national adaptation plans are implemented (UNFCCC, 2007 in WACD1, 2011). Rural people are most vulnerable to the impacts of climate change as they depend mostly on their land and natural environment for their livelihood. Although indigenous peoples" "low-carbon" traditional ways of life have contributed little to climate change; indigenous peoples are the most adversely affected by it (Raygorodetsky, et al., 2011). Climate change poses a growing threat to their survival, yet, they continue to be excluded from the global processes of decision and policymaking with regards to climate change mitigation options.

Climate change issues are a global challenge and scientists alone may not be able to provide lasting solutions to the menace. Therefore, it is pertinent to think of other ways to tackle the problem. In view of this, the importance of indigenous knowledge cannot be over emphasized and there is much to learn from indigenous, traditional and community-based approaches to natural disaster preparedness. Indigenous knowledge makes an important contribution to climate change policy and Sustainable Development Goal 13 on climate action; by observing changing climates, adapting to impacts and contributing to global mitigation efforts (UNESCO, 2019). It includes understanding of how to cope with and adapt to environmental variability and trends. Incorporating indigenous knowledge into climate change policies can lead to the development of effective mitigation and adaption strategies that are cost-effective, participatory and help in food crop production (Robinson and Herbert, 2010). The indigenous farmers' level of awareness seems to be on increase regarding their experience in change and length of seasons, incidence of environmental hazards such as flood, droughts and crop failures, long term shift in wind speed, change in rainfall intensity and uncertainty of rain etc. (Morghadiya and Smarden, 2011).

Indigenous people have been confronted with changing environments for millennia and have developed a wide array of coping strategies. Their traditional knowledge and practices provide an important basis for facing the even greater challenges of climate change. Some indigenous practices identified in agricultural production to mitigate and adapt to climatic changes includes; building of burrows, multiple cropping, application of green manure and crop rotation (Prakash, 2002).

Given the importance of indigenous knowledge in reducing the impacts of climate change on agricultural production, the study focused on the assessment of food crop farmers' indigenous strategies in climate change mitigation and adaptation in Imo State. The study specifically is designed to; ascertain food crop farmers' awareness of climate change; determine the farmers' perceived effects of climate change on food crop production in the study area; identify the indigenous strategies adopted in climate change mitigation and adaptation as well as identify constraints faced by farmers in mitigating and adapting to climate change in the study area.

\section{MATERIALS AND METHODS}

The study was conducted in Imo State which is among the five States in South-East Nigeria. The State is located between latitudes $5^{\circ} 10^{1}$ and $5^{\circ} 51^{1}$ North and longitude $6^{\circ} 35^{1}$ and $7^{\circ} 28^{1}$ East, with a total land mass area of $5,289.49 \mathrm{~km}^{2}$ and a total population of $3,934,899$ persons (NBS, 2007) with many subsisting in farming. The State has an average annual temperature of $28^{\circ} \mathrm{C}$, an average annual relative humidity of $80 \%$, average annual rainfall of $1800-2500 \mathrm{~mm}$ and an altitude of about $100 \mathrm{~m}$ above sea level (Imo ADP, 1990). The State has three agricultural zones namely Orlu, Owerri, and Okigwe agricultural zones. It is also delineated into 27 local government areas. The 
population of the study comprised of all crop farmers in Imo state. Two local government areas were randomly chosen from the three agricultural zones. From the selected Local Government Areas, two communities were selected randomly making it a total of six (6) communities sampled for the study. One village was then randomly selected from each of the communities to give a total of six (6) villages sampled. The list of contact food crop farmers which form the sampling frame for the survey was obtained from the Agricultural Development Programme (ADP) office in the State. From this list, twelve (12) practicing food crop farmers were sampled from each village sampled to give a total sample size of seventy two (72) food crop farmers for the study.

Data collected were analysed using descriptive statistics like frequency, percentage, mean and standard deviation. A 3 point Likert-type scale rating was used to elicit responses on the farmers perceived effect of climate change on food crop production. The mean scores for the 3-piont Likert scale rating was obtained by adding up the weighted values and dividing by the number of scales; Agreed (3), Disagreed (2), Undecided (1) then divided by the number of scales to obtain the discriminating index $($ e.g $3+2+1 / 3=2.0)$. The significant mean was 2.0 and above.

\section{RESULTS AND DISCUSSION}

\section{Awareness of Climate change}

The distribution of respondents about their awareness of climate change in the study area is presented on Table 1. The results revealed that majority (95.83\%) of the respondents were aware of climate change while the remaining $4.17 \%$ of the respondents were unaware of climate change. With a greater percentage of the respondents aware of climate change, it is an indication that the rural farmers were informed about climate change trends in the study area. Awareness of climate change would inform the farmer's decision to adopt adaptation and mitigation strategies to reduce the impacts in their agricultural production. The findings are consistent with the results of Nwajiuba, Onyeneke and Munonye (2008).

\section{Farmers perceived effects of climate change on crop production}

The farmers perceived effects of climate change on crop production are presented in Table 2. From the results, all the items listed had mean scores above the cut-off point (discriminatory index) of 2.0 and hence implies that the farmers perceived these climate change factors had effects on crop production. The farmers perceived that droughts after planting reduces crop yield (Mean $=2.44$, $\mathrm{SD}=0.802$ ). The farmers perceived that late onset of rain reduces crop yield with a mean score of 2.43 ( $\mathrm{SD}=0.784)$. Also, perceived that 'late onset of rain leads to late planting of crops' (Mean $=2$. 42; $\mathrm{SD}=0.800$ ) and 'Climate change increases the incidence of pests and diseases infestations in crop farms' $($ Mean $=2.41$; SD $=0.782$ ) were perceived by the food crop farmers as climate change effects on crop production in the study area. Previous study by Nwalieji and Uzuegbunam (2012) indicate that crop yields are negatively affected by climate change.

\section{Farmers Indigenous Strategies to Climate change mitigation and adaptation}

Farmers' indigenous strategies to climate change mitigation and adaption is shown in Table 3. From the result of the survey, $69.44 \%$ identified "use of disease resistant varieties" as an indigenous strategy they use to adapt to climate change effects. Other measures identified were "livelihood diversification, agro forestry, adjustment of planting dates, mulching, mixed farming and cover cropping $(58.33 \%, 37.50 \%, 63.89 \%, 56.94 \%, 65.28 \%$ and 59.72\%) respectively, as

\section{Journal of the Faculty of Agriculture and Veterinary Medicine, Imo State University Owerri} website: www ajol.info 
indigenous strategies to climate change mitigation and adaptation. Planting of trees which is an important agro forestry practice was practiced by $15.28 \%$ of the respondents. Nwaiwu et al. (2014) in a study on climate change trends and appropriate mitigation and adaptation measures in South East Nigeria found that farmers use mulching, mixed cropping, planting of cover crops as options for mitigating and adapting to climate change.

\section{Constraints faced by farmers in mitigating and adapting to climate change effects}

The survey result in Table 4 revealed that higher proportion of the respondents $(72.22 \%)$ and $(70.83 \%)$ identified high labour cost and poor storage and processing facilities respectively, as the major constraints faced by farmers in mitigating and adapting to climate change effects. $(69.44 \%$, $54.16 \%, 52.78 \%, 50.00 \%, 41.67,41.67$ and 33.33\%) identified inadequate production capital, limited availability of farm land, poor access to credit, poor quality of seedlings, long distance between farms and market, inadequate information, and poor extension contact respectively as constraints faced by farmers in mitigating and adapting to climate change effects. The result suggests that farmers are limited in adaptation strategies adopted by a myriad of constraints. This may be an indication of their vulnerability to the effect of climate change.

\section{CONCLUSION}

Majority of the farmers were aware of climate change and use certain indigenous strategies to mitigate the effects of climate change on their agricultural activities. Adaptive and mitigating measures to climate change will need active and sustained efforts of stakeholders; government, donor agencies and individuals in Nigeria. The study recommends the establishment of research institutes to investigate successful indigenous adaptation and mitigation measures for scaling up and down. Also, agricultural extension advisory services should be intensified in all the States to educate farmers on successful indigenous strategies to mitigate climate change effect on crop production. 


\section{REFERENCES}

Environmental Protection Agency accessed 12/07/2018. Available online: https://www.epa.gov/ghgemissions/sources-greenhouse-gas-emissions

Imo State Agricultural Development Programme (ADP) (1990). Work Programme

IPCC (2007) Summary for Policymakers. In: Climate Change 2007: Impacts, Adaptation and Vulnerability. Contribution of Working Group II to the Fourth Assessment Report of the Intergovernmental Panel on Climate Change, M.L. Parry, O.F. Canziani, J.P. Palutikof, P.J. van der Linden and C.E. Hanson, Eds., Cambridge University Press, Cambridge, UK, 7-22.

Intergovernmental Panel on Climate Change (IPCC) (2010).Contribution of working Group to the Fourth Assessment Report of the IPCC-Summary for policy-makers. Retrieved March 8, 2010 from http://www.ipcc.ch:

Morghadiya. R.and Smarden, R.S. (2011). Farmers perception of Risk, Impacts and Adaptation to Climate Change. Perspective from Western India Dinesh: College of Environmental Science and Forestry.

National Bureau of Statistics (NBS) (2007). Breakdown of the National and State Provisional Totals, 2006 Census. National Bureau of Statistics Official Gazette; www.nigerianstat.gov.ng

Nwaiwu, I.U.O; Ohajianya, D.O.; Orebiyi,J.S., Ibekwe, U.C., Lemchi, J.I.; Onyeagocha, S.U.O.; Odoemena, B.; Utazi; C.O.; Osuagwu, C.O. \& Tasie C.M. (2014). Climate Change Trend and Appropriate Mitigation and Adaptation Strategies in SouthEast Nigeria. Global Journal of Biology, Agriculture and Health Sciences, 3(1):120-125.

Nwajiuba, C.U.; Onyeneke, Rand Munonye, J. (2008). Climate Change: Perception and Adaptation by Poultry Farmers in Imo State. In : Nwajiuba C.(ed), Climate Change and Adaptation in Nigeria. Farming and Rural Systems Economics by Doppler W. and Bauer S., Volume 95, Margraf Publishers, Hohenheim, Germany.

Nwalieji, H.U. and Uzuegbunam, C.O. (2012). Effect of Climate Change on Rice Production in Anambra State, Nigeria Journal of Agricultural Extension, 16 (2): 81 - 91. http://dx.doi.org/10.4314/jae.v16i2.7

Prakash S. (2002). Using Indigenous Knowledge to raise Agricultural Productivity: An example from India. Indigenous knowledge (IK) notes. No 45. World Bank Washington DC. http//hdl.handle.net/10980/10793.

Raygorodetsky, G. (2011). Why Traditional Knowledge Holds the Key to Climate Change. United Nations University, Japan. Available online on: https://unu.edu/publications/articles/whytraditional-knowledge-holds-the-key-to-climate-change.html

UNESCO (2019). Indigenous Knowledge and Climate Change. Available online: https://en.unesco.org/links/climatechange

Women and Children Development Initiative (WACDI), (2011). Gender Dimensions and Indigenous Knowledge for Adaptation to Climate Change in South East Nigeria. A Research Report. www.imostate.gov.ng 
Table 1: Distribution of respondents based on awareness of climate change

\begin{tabular}{lll}
\hline Awareness of climate change & Frequency & Percentage (\%) \\
\hline No & 3 & 4.17 \\
Yes & 69 & 95.83 \\
\hline Total & $\mathbf{7 2}$ & $\mathbf{1 0 0 . 0 0}$ \\
\hline
\end{tabular}

Source: Own computation from field survey data, 2018.

Table 2: Distribution of respondents based on perceived effects of climate change on crop production

$\begin{array}{cccccc}\text { Agree } & \text { Disagree } & \text { Undecided } & \text { Total } & \text { Mean } & \text { SD } \\ (3) & (2) & (1) & \text { score } & \text { score } & \end{array}$

\begin{tabular}{|c|c|c|c|c|c|c|c|c|c|}
\hline Items & Freq & Score & Freq & Score & Freq & Score & & & \\
\hline $\begin{array}{l}\text { 1. Late onset of rain } \\
\text { reduces crop yield. }\end{array}$ & 44 & 132 & 15 & 30 & 13 & 13 & 75 & $2.43^{*}$ & 0.784 \\
\hline $\begin{array}{l}\text { 2. Late onset of rain } \\
\text { leads to late planting } \\
\text { of crops. }\end{array}$ & 44 & 132 & 14 & 28 & 14 & 14 & 174 & $2.42^{*}$ & 0.800 \\
\hline $\begin{array}{l}\text { 3. Droughts after } \\
\text { planting reduces crop } \\
\text { yield. }\end{array}$ & 46 & 138 & 12 & 24 & 14 & 14 & 176 & $2.44^{*}$ & 0.802 \\
\hline $\begin{array}{l}4 . \quad \text { Increased } \\
\text { incidence of pests and } \\
\text { diseases infestations }\end{array}$ & 37 & 111 & 22 & 44 & 13 & 13 & 168 & $2.33^{*}$ & 0.782 \\
\hline $\begin{array}{l}\text { 5. Crop failure due to } \\
\text { climate change leads } \\
\text { to food insecurity }\end{array}$ & 43 & 129 & 16 & 32 & 13 & 13 & 187 & $2.41 *$ & 0.782 \\
\hline $\begin{array}{l}\text { 6. Climate change } \\
\text { reduces soil fertility }\end{array}$ & 33 & 99 & 24 & 48 & 15 & 15 & 162 & $2.25^{*}$ & 0.782 \\
\hline
\end{tabular}

Source: Own computation from field survey data, 2018.

*High responses 
Chidiebere-Mark, N.M. Ejike, R.D., Nwaiwu, J.C., Nwankwo, O.O. \& Ibe, G.O.

100- 106

Journal of Agriculture and Food Sciences

Volume 16 Number 2, October 2018 pp

Table 3: Distribution of farmers based on indigenous strategies to climate change mitigation and adaptation

\begin{tabular}{lll}
\hline $\begin{array}{l}\text { Indigenous Strategies to climate change } \\
\text { mitigation and adaptation }\end{array}$ & Frequency* & Percentage (\%) \\
\hline Livelihood diversification & 42 & 58.33 \\
Use of disease resistant varieties & 50 & 69.44 \\
Agro forestry & 27 & 37.50 \\
Adjustments in planting dates & 46 & 63.89 \\
Mulching & 41 & 56.94 \\
Planting of trees & 11 & 15.28 \\
Mixed farming & 47 & 65.28 \\
Intercropping & 17 & 23.61 \\
Zero tillage & 10 & 13.89 \\
Cover cropping & 43 & 59.72 \\
\hline
\end{tabular}

Source: Field survey data, 2018.

* Multiple responses recorded

Table 4: Constraints faced by farmers in mitigating and adapting to climate change effects

\begin{tabular}{lll}
\hline Constraints & Frequency & Percentage* \\
\hline High Labour cost & 52 & 72.22 \\
Inadequate Production Capital & 50 & 69.44 \\
Limited availability of farmland & 39 & 54.16 \\
Long distance between farms and market & 30 & 41.67 \\
Poor quality of seedlings & 36 & 50.00 \\
Poor Extension Contact & 24 & 33.33 \\
Inadequate Information & 30 & 41.67 \\
Poor access to credit & 38 & 52.78 \\
Poor Storage and processing facilities & 51 & 70.83 \\
\hline
\end{tabular}

Source: Own computation from field survey data, 2018

*Multiple responses recorded

Journal of the Faculty of Agriculture and Veterinary Medicine, Imo State University Owerri website: www ajol.info 